\title{
Hubungan antara perilaku ibu tentang kebersihan dan frekuensi kejadian Gastroentritis pada balita usia 1 - 3 tahun di RS Adi Husada Kapasari Surabaya
}

\author{
Ernawatik¹, Nyna Puspitaningrum²
}

1. Mahasiswi Program Studi D-III Kebidanan Universitas PGRI Adi Buana Surabaya

2. Tenaga Pengajar Program Studi D III Kebidanan Universitas PGRI Adi Buana Surabaya

\section{ABSTRAK}

Gastroentritis merupakan penyebab utama morbiditas dan mortalitas pada anak di seluruh dunia, dimana pada balita daya tahan tubuh masih sangat rentan terhadap penyakit. Selain itu penyakit gastroentritis pada balita juga dipengaruhi oleh perilaku ibu, karena balita sangat tergantung pada ibu dalam melakukan kegiatan sehari-hari. Tujuan penelilian ini adalah untuk menganalisa hubungan perilaku ibu tentang kebersihan dan frekuensi kejadian gastroentritis pada balita usia 1-3 tahun. Jenis penelitian yang digunakan analitik kuantitatif dengan desain penelitian cross sectional yang dilaksanakan pada tanggal 1 April - 31 Mei 2010 di RS Adi Husada Kapasari, uji statistik dengan menggunakan sperman rank. Berdasarkan hasil penelitian diperoleh hasil bahwa sebagian besar (56\%) ibu berperilaku tidak sehat dan sebagian besar (60\%) balita usia 1-3 tahun terserang GE > 3x dalam kurun waktu 3 bulan. Dan hasil sperman rank didapatkan $t_{\text {hitung }} 9,39>t_{\text {tabel }} 2,048$, jadi $H_{0}$ ditolak dan $\mathrm{H}_{1}$ diterima, yang menyatakan terdapat hubungan perilaku ibu tentang kebersihan dan frekuensi kejadian GE pada balita usia 1-3 tahun. Oleh sebab itu perlu adanya penyuluhan tentang pentingnya membiasakan ibu untuk berperilaku hidup sehat sebagai upaya untuk pencegahan penyakit gastroenteritis pada balita.

Kata Kunci : Perilaku, Gastroentritis, balita usia 1 - 3 tahun

\section{PENDAHULUAN}

Angka kematian pada balita di Indonesia pada tahun 2007 masih cukup tinggi yaitu 45:1000 kelahiran hidup. Penyebab kematian anak adalah infeksi pernafasan akut, komplikasi pasca persalinan, diare, tetanus, meningitis, thypus, malaria serta kekurangan gizi (www.tempointeraktif.com). Menurut riset kesehatan dasar (Riskesdas) tahun 2007 beberapa penyakit utama yang menjadi penyebab kematian pada balita adalah penyakit diare sebanyak 25,2\%; pneumonia $15,5 \%$; Demam Berdarah Dengue 6,8\% dan campak sebanyak 5\% (www.infodokterku.com).

Penyakit diare atau dalam bidang kesehatan lebih sering di sebut dengan istilah gastroentritis, hingga kini masih menjadi salah satu penyebab utama morbiditas dan mortalitas pada anak diseluruh dunia yang menyebabkan kejadian sakit dan 3-4 kasus kematian setiap tahunnya (Nelson, 1999 : 889). GastroEntritis (GE) sering dianggap penyakit sepele, pada tingkat global dan nasional fakta menunjukkan sebaliknya. Di Asia, Afrika dan Amerika Latin diperkirakan 3-5 milliar episode diare menimbulkan 5-6 juta kasus kematian. (Rudolph, 2006 : 719), sedangkan di Indonesia diperkirakan terdapat lebih 60 juta kejadian GE setiap tahunnya.

Sebagian besar penderitaadalah anak-anak dibawah usia 5 tahun( $60-80 \%$ ), sehingga terdapat kurang lebih 40 juta kejadian GE pada setiap tahunnya. (Sudarmo, M.S., dkk, 2004 : 41). Menurut catatan WHO, GE membunuh 2,2 juta anak di dunia setiap tahunnya, sedangkan di Indonesia menurut survei kesehatan nasional (Surkesnas) tahun 2001, GE merupakan 
penyebab kematian kedua terbesar pada balita (www. medicastore.com).

GE merupakan infeksi saluran pencernaan, dimana keadaan frekuensi buang air besar lebih dari 4x pada bayi dan lebih dari 3x pada anak, konsistensi feaces encer, dapat berwarna hijau atau dapat pula bercampur lendir dan darah atau lendir saja. (Ngastiyah 1997 : 143). Di Negara berkembang maupun negara maju, rotavirus merupakan penyebab GE yang penting pada bayi dan balita, yang ditularkan melalui rute masa oral atau fecal-oral (Rudolph, 2006 : 719). Pada umumnya penyakit GE terjadi pada lingkungan yang padat penduduk, tinggal berdesakan, kebersihan yang buruk dan sanitasi yang jelek, serta terjadi pada saat pergantian musim (Wong, 2006 : 999).

Berbagai perilaku kebersihan ibu seperti kebiasaan tidak mencuci tangan dengan sabun sesudah buang air besar atau sebelum menjamah makanan, memudahkan penularan penyakit GE yang ditularkan melalui fecal-oral, tidak membiasakan balita buang air besar di toilet, dimana pada tinja terdapat rotavirus yang dapat hidup berminggu-minggu di luar tubuh manusia serta penggunaan botol susu yang tidak disterilkan kembali setelah dipakai kemungkinan meningkatkan resiko terjadinya diare pada bayi dan balita (Nursalam, dkk, 2005 : 169). Balita dapat mengalami lebih dari satu kali kejadian diare setiap tahunnya (Sudarmo. M.s, dkk, 2004 : 41).

Menurut data survey baseline Environment Services Program (ESP - USAID) tahun 2006, fakta menunjukan bahwa masih rendahnya kebiasaan untuk membersihkan tangan dengan menggunakan sabun, pada saat penting di masyarakat yaitu sebelum makan 14,3\%; sesudah buang air besar 11,7\%; setelah memberi minum bayi $8,9 \%$; sebelum menyuapi anak $7,4 \%$ dan sebelum menyiapkan makanan $6 \%$. (www.kr.co.id).

Di RS Adi Husada Kapasari Surabaya, angka kejadian GE merupakan angka yang tertinggi di banding penyakit lainnya di ruang rawat inap anak. Berdasarkan data yang diperoleh di ruang rawat inap anak RS. Adi
Husada Kapasari Surabaya pada tahun 2007 2009 :

- Tahun 2007 jumlah seluruh penderita di ruang rawat inap anak 1.493, jumlah pasien GE sebanyak 414 (27,7\%), dengan jumlah pasien GE pada balita usia 1-3 tahun, 156 (39,6\%).

- Tahun 2008 jumlah seluruh penderita di ruang rawat inap anak 1.532 , jumlah pasien GE sebanyak 430 (28,1\%), dengan jumlah pasien GE pada balita usia 1-3 tahun, 139 (34,7\%).

- Tahun 2009 jumlah seluruh penderita di ruang rawat inap anak 1.516, jumlah pasien GE sebanyak 447 (29,5\%), dengan jumlah pasien GE pada balita usia 1-3 tahun, 194 (45,3\%).

Berdasarkan uraian diatas dapat disimpulkan bahwa kebersihan yang buruk dan sanitasi yang jelek merupakan pokok utama timbulnya GE, maka dengan dilaksanakannya kebiasaan untuk membersihkan tangan dengan menggunakan sabun serta menjaga kebersihan dapat mengurangi faktor pendorong GE. Sehingga dapat ditarik suatu rumusan masalah yakni apakah ada hubungan antara perilaku ibu tentang kebersihan dan frekuensi kejadian GE pada balita usia 1-3 tahun di RS Adi Husada kapasari Surabaya ? Tujuan umum penelitian adalah mengetahui hubungan antara perilaku ibu tentang kebersihan dan frekuensi kejadian GE pada balita usia 1-3 tahun. Tujuan khusus dari penelitian ini adalah :

- Mengidentifikasi frekuensi kejadian Gastroentritis pada balita usia 1-3 tahun di RS Adi Husada Kapasari Surabaya.

- Mengidentifikasi perilaku ibu tentang kebersihan yang balitanya menderita Gastroentritis di RS Adi Husada Kapasari Surabaya.

- Menganalisis hubungan perilaku ibu tentang kebersihan dan frekuensi kejadian Gastroentritis pada balita usia 1-3 tahun di RS Adi Husada Kapasari Surabaya.

\section{BAHAN DAN METODE}

Jenis penelitian yang digunakan adalah analitik kuantitatif dengan desain penelitian cross sectional dimana variabel-variabel yang 
termasuk faktor dan variabel yang termasuk efek di observasi sekaligus pada saat yang sama. Populasi penelitian ini adalah seluruh ibu yang balitanya menderita GE dan berusia 1-3 tahun di ruang rawat inap anak di RS Adi Husada Kapasari Surabaya.Total sampel yaitu 30 orang dengan teknik sampling jenuh.

Variabel independent dalam penelitian ini adalah perilaku ibu tentang kebersihan yang balitanya menderita GE dan variabel dependen yaitu frekuensi kejadian GE pada balita usia 1-3 tahun.

Prosedur pengumpulan data dengan menggunakan angket. Yang berisi 10 pertanyaan tentang perilaku ibu dengan 3 pilihan jawaban :

1. Jawaban 1 nilai kurang;

2. Jawaban 2 nilai cukup;

3. Jawaban 3 nilai baik

Skor total : 30

Dari penilaian perilaku ibu diatas maka perumusan skor sebagai berikut :

- $15-20$ : perilaku ibu tidak sehat.

- 21-25: perilaku ibu kurang sehat.

- 26-30 : perilaku ibu sehat

Satu pertanyaan tentang kejadian GE pada balita dengan 3 pilihan jawaban sebagai berikut :

1. Bila balita terserang GE 1 kali dalam kurun waktu 3 bulan nilai 3;

2. Bila balita terserang GE 2 - 3 kali dalam kurun waktu 3 bulan nilai 2;

3. Bila balita terserang GE $>3$ kali dalam kurun waktu 3 bulan nilai 1 .

Skor total : 3 .

Gambar 1 - Kerangka konseptual hubungan perilaku ibu tentang kebersihan dan frekuensi kejadian GE pada balita usia 1-3 tahun.

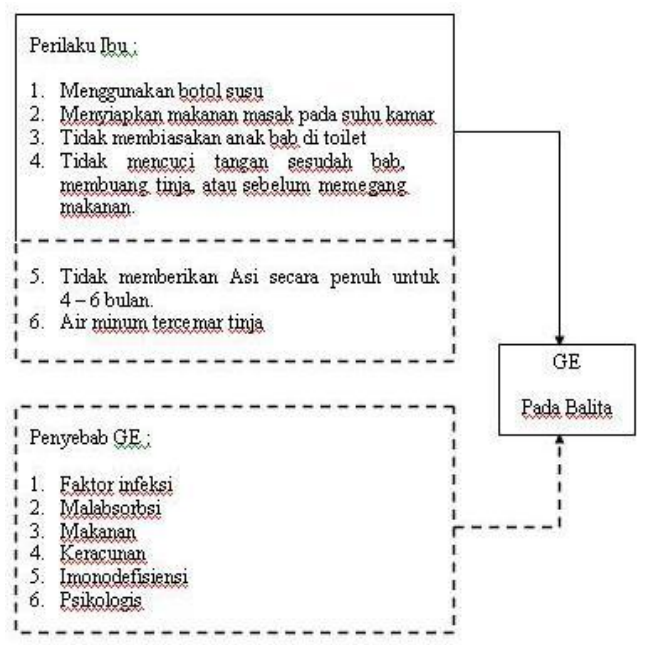

Keterangan :

$\square$ : Diteliti

: Tidak di teliti

Pada gambar 1 dapat dijelaskan bahwa GE pada balita dapat disebabkan oleh faktor infeksi, malabsorbsi, makanan, keracunan, imuno defisiensi dan psikologis dan faktor perilaku ibu tentang kebersihan yang dapat meningkatkan kejadian GE pada balita. Pada penelitian ini penulis hanya membatasi subjek yang di teliti yaitu semua ibu yang balitanya menderita penyakit GE dan semua balita yang berusia 1-3 tahun menderita GE di ruang rawat inap anak RS Adi Husada Kapasari Surabaya.

Dalam penelitian ini di rumuskan hipotensis sebagai berikut :

$\mathrm{H}_{1}$ ada hubungan antara perilaku ibu tentang kebersihan dan frekuensi kejadian GE pada Balita usia 1-3 tahun di RS Adi Husada Kapasari Surabaya.

Analisis untuk mengetahui hubungan menggunakan Uji korelasi Sperman Rank dengan tingkat kemaknaan $\alpha 0,05$ dengan rumus

$\mathrm{rs}=\frac{\sum x^{2}+\sum y^{2}-\sum d i^{2}}{2 \sqrt{\sum x^{2} \sum y^{2}}}$

Keterangan :

rs = Koefisien korelasi Sperman Rank

$d i=$ Selisih setiap pasangan rank

Pengujian para meter koefisien korelasi menggunakan :

$\mathrm{t}=\frac{\mathrm{rs} \sqrt{\mathrm{n}-2}}{\sqrt{1-\mathrm{r}_{\mathrm{s}}^{2}}}$

Untuk mengetahui ada tidaknya hubungan kedua variabel dibandingkan dengan tabel $\mathrm{t}$.

Keterangan :

$\mathrm{H}_{\mathrm{o}}$ ditolak jika $\mathrm{t}>$ nilai $\mathrm{t}$ tabel

$\mathrm{H}_{1}$ diterima jika $\mathrm{t}>$ nilai $\mathrm{t}$ table

\section{HASIL DAN PEMBAHASAN}

Berikut ini uraian hasil penelitian yang telah dilakukan di ruang rawat inap anak RS Adi Husada Kapasari Surabaya 
Tabel 1 - Tabel distribusi frekuensi berdasarkan perilaku ibu tentang kebersihan di ruang rawat inap anak RS Adi Husada Kapasari

\begin{tabular}{ccc}
\hline $\begin{array}{c}\text { Perilaku Ibu } \\
\text { tentang } \\
\text { Kebersihan }\end{array}$ & Frekuensi (f) & Prosentase (\%) \\
\hline $\begin{array}{c}\text { Perilaku tidak } \\
\text { sehat }\end{array}$ & 17 & 57 \\
$\begin{array}{c}\text { Perilaku kurang } \\
\text { sehat }\end{array}$ & 5 & 17 \\
$\begin{array}{c}\text { Perilaku sehat } \\
\text { Jumlah }\end{array}$ & 8 & 26 \\
\hline
\end{tabular}

Dari table 1 dapat dijelaskan sebagian besar 17 orang (57\%) berperilaku hidup tidak sehat.

Tabel 2 - Tabel distribusi frekuensi berdasarkan frekuensi kejadian GE pada balita usia 1-3 tahun di ruang rawat inap anak RS Adi Husada

\section{Kapasari}

\begin{tabular}{ccc}
\hline $\begin{array}{c}\text { Frekuensi kejadian GE pada } \\
\text { balita usia 1-3 tahun }\end{array}$ & $\begin{array}{c}\text { Frekuensi } \\
\text { (f) }\end{array}$ & $\begin{array}{c}\text { Prosentase } \\
\text { (\%) }\end{array}$ \\
\hline $\begin{array}{c}\text { Terserang GE > 3x dalam kurun } \\
\text { waktu 3 bulan }\end{array}$ & 18 & 60 \\
$\begin{array}{c}\text { Terserang GE 2-3x dalam kurun } \\
\text { waktu 3 bulan }\end{array}$ & 7 & 23 \\
$\begin{array}{c}\text { Terserang GE 1x dalam kurun } \\
\text { waktu 3 bulan }\end{array}$ & 5 & 17 \\
\hline Jumlah & 30 & 100 \\
\hline
\end{tabular}

Berdasarkan table 2 dapat dijelaskan sebagian besar 18 balita (60\%) terserang penyakit GE lebih dari 3x dalam kurun waktu 3 bulan.
Tabel 3 - Tabulasi silang perilaku ibu tentang kebersihan dan frekuensi kejadian GE di ruang rawat inap anak RS Adi Husada Kapasari

\begin{tabular}{|c|c|c|c|c|c|c|c|c|}
\hline $\begin{array}{r}\text { Frekuensi } \\
\text { kejadian } \\
\text { GE }\end{array}$ & \multicolumn{2}{|c|}{$\begin{array}{c}\text { Terseran } \\
\mathbf{g} \\
\text { GE }>\mathbf{3 x}\end{array}$} & \multicolumn{2}{|c|}{$\begin{array}{c}\text { Terseran } \\
\text { g GE 2- } \\
3 \mathbf{x}\end{array}$} & \multicolumn{2}{|c|}{$\begin{array}{c}\text { Terseran } \\
\text { g GE 1x }\end{array}$} & \multicolumn{2}{|c|}{ Total } \\
\hline & $f$ & $\%$ & f & $\%$ & $f$ & $\%$ & f & $\%$ \\
\hline $\begin{array}{c}\text { Perilaku } \\
\text { tidak sehat }\end{array}$ & $\begin{array}{l}1 \\
7\end{array}$ & 100 & 0 & 0 & 0 & 0 & $\begin{array}{l}1 \\
7\end{array}$ & 100 \\
\hline $\begin{array}{c}\text { kurang } \\
\text { sehat }\end{array}$ & 1 & 20 & 4 & 80 & 0 & 0 & 5 & 100 \\
\hline $\begin{array}{l}\text { Perilaku } \\
\text { sehat }\end{array}$ & 0 & 0 & 3 & 37 & 5 & 63 & 8 & 100 \\
\hline Jumlah & $\begin{array}{l}1 \\
8\end{array}$ & & 7 & & 5 & & $\begin{array}{l}3 \\
0\end{array}$ & \\
\hline$\alpha=0,05$ & & & & 9,39 & & & . & \\
\hline
\end{tabular}

Dari hasil analisa dengan menggunakan uji statistic sperman rank dengan kemaknaan $\alpha=$ 0,05 didapatkan bahwa $t_{\text {hitung }} 9,39>t_{\text {tabel }} 2,048$ dapat disimpulkan $\mathrm{Ho}$ ditolak dan $\mathrm{H}_{1}$ diterima hal ini terdapat hubungan antara perilaku ibu tentang kebersihan dan frekuensi kejadian GE pada balita usia 1-3 tahun di ruang rawat inap anak RS Adi Husada Kapasari bahwa sebagian besar perilaku ibu tidak sehat menyebabkan 17 balita terserang penyakit GE $>3 x$ dalam kurun waktu 3 bulan.

Berdasarkan hasil penelitian, terdapat hubungan antara perilaku ibu tentang kebersihan dan frekuensi kejadian GE pada balita usia 1-3 tahun di ruang rawat inap anak RS Adi Husada Kapasari Surabaya yang telah diuji dengan menggunakan sperman rank. Data yang didapatkan di ruang rawat inap anak RS Adi Husada Kapasari sebagian besar (57\%) ibu berperilaku tidak sehat dan sebagian besar $(60 \%)$ balita terserang penyakit GE $>3 x$ dalam kurun waktu 3 bulan.

Dari hasil sperman rank dengan taraf signifikan $\alpha 0,05(5 \%)$, nilai $t_{\text {hitung }}$ sebesar 9,39 
sedangkan nilai $t_{\text {tabel }} 2,048$. Karena nilai $t_{\text {hitung }}>$ dari $t_{\text {tabel }}(9,39>2,048)$ maka $\mathrm{H}_{\circ}$ ditolak dan $\mathrm{H}_{1}$ diterima sehingga dapat disimpulkan, terdapat hubungan antara perilaku ibu tentang kebersihan dan frekuensi kejadian GE pada balita usia 1 - 3 tahun, dapat dikatakan bahwa ibu yang berperilaku tidak sehat menyebabkan balita lebih rentan dan lebih sering terserang penyakit GE.

Hal ini sesuai dengan (Sulika, dkk, 2002) bahwa perilaku sehat dipengaruhi adanya faktor internal keluarga seperti halnya ibu atau masyarakat yang mempermudah untuk berperilaku hidup sehat. Seorang ibu memegang peranan penting bagi kesehatan balitanya, dimana pada balita usia 1-3 tahun sangat tergantung pada ibu dalam melakukan aktivitas sehari-hari. Perilaku hidup ibu yang tidak sehat seperti penggunaan botol susu dan cara penyeterilan botol susu yang salah, tidak membiasakan balita untuk BAB di toilet, membuang tinja selain di toilet, tidak mencuci tangan sesudah buang air besar, sesudah membuang tinja atau sebelum memegang makanan merupakan faktor resiko yang dapat meningkatkan terjadinya GE pada balita. (Nursalam, dkk, 2005).

Berdasarkan hasil penelitian ini ditemukan pula sebanyak 3 balita yang terserang penyakit GE 2-3x dalam kurun waktu 3 bulan pada ibu yang mempunyai perilaku sehat. Hal ini dikarenakan GE pada balita tidak hanya disebabkan karena perilaku ibu saja, tetapi juga dapat dipengaruhi oleh faktor lain, yaitu infeksi enteral atau parenteral, malabsorsi karbohidrat, lemak, protein dan keracunan maupun disebabkan oleh defisiensi imun terutama SIgA serta sanitasi yang jelek dan tingkat pendidikan yang rendah, namun dalam penelitian ini faktorfaktor tersebut tidak diteliti.

\section{SIMPULAN DAN SARAN}

Berdasarkan data analisis maka dapat disimpulkan sebagai berikut :

1. Sejumlah 17 responden (57\%) ibu berperilaku hidup tidak sehat yang balitanya berusia 1-3 tahun menderita GE di ruang rawat inap anak RS Adi Husada Kapasari Surabaya.
2. Sejumlah 18 responden $(60 \%)$ balita usia 1-3 tahun terserang penyakit $\mathrm{GE}>3 \mathrm{x}$ dalam kurun waktu 3 bulan.

3. Terdapat hubungan antara perilaku ibu tentang kebersihan dan frekwensi kejadian GE pada balita usia 1-3 tahun di ruang rawat inap anak RS Adi Husada Kapasari Surabaya.

Berdasarkan hasil penelitian diatas maka diharapkan bagi masyarakat, khususnya :

1. Bagi ibu, diharapkan dapat meningkatkan perilaku hidup sehat, sebagai upaya untuk mencegah penyakit GE pada balita, yang dapat diawali dengan hal yang paling sederhana yaitu membiasakan cuci tangan dengan sabun.

2. Bagi perawat, diharapkan perawat dapat memberikan penyuluhan kepada ibu tentang pentingnya kebiasaan hidup sehat, pencegahan serta penularan penyakit GE sehingga dapat mengurangi periode kejadian penyakit GE pada balita serta memberikan asuhan keperawatan secara menyeluruh.

3. Bagi Rumah Sakit, diharapkan untuk dapat meningkatkan pengetahuan perawat agar mampu memberikan pelayanan keperawatan yang optimal melalui seminar-seminar atau pelatihan. Serta pemasangan poster tentang cara mencuci tangan yang benar, sanitasi lingkungan, cara pencucian dan penyeterilan botol susu, yang dapat dengan mudah dibaca atau dipahami oleh orang tua khususnya ibu balita.

\section{DAFTAR ACUAN}

Eko Budiarto, 2003 : Metodologi Penelitian Kedokteran Sebuah Pengantar, Jakarta : GEC.

Hartanto Sunardi dan Wara Pramesti, 2008 : Statistika Surabaya University Press Adi Buana.

Heri Purwanto, 1998 : Pengantar Perilaku Manusia, Jakarta : EGC.

Hurlock, B., 1998 : Perkembangan Anak, Jakarta : Erlangga.

Machfoedz, I, dkk, 2005 : Pendidikan Kesehatan Bagian dari Promosi Kesehatan, Yogyakarta: Fitramaya. 
Nelson, 1999 : Ilmu Kesehatan Anak, Jakarta : EGC.

Ngastiyah, 1997 : Perawatan Anak Sakit, Jakarta : EGC.

Ngastiyah, 2005 : Perawatan Anak Sakit, Jakarta : EGC.

Nursalam, dkk., 2005 : Asuhan Keperawatan Bayi dan Anak, Jakarta : Salemba Medika.

Nursalam, 2008 : Konsep dan Penerapan Metodologi Penelitian IImu Keperawatan, Jakarta : Salemba Medika.

Rudolph, C., 2006 : Buku Ajar Pediatri Rudolph, Jakarta : EGC.

Sastroasmoro dan Sofyan Ismael, 2002 : Dasardasar Metodologi Penelitian Klinis, Jakarta : CV Sagung Seto.

Soekidjo Notoatmodjo, 2003 : Pendidikan dan Perilaku Kesehatan, Jakarta : Rineka Cipta

Soekidjo Notoatmodjo, 2005 : Metodologi Penelitian Kesehatan, Jakarta : Rineka Cipta.

Soetjiningsih, 1995 : Tumbuh Kembang Anak, Jakarta : EGC

Sudarmo, S., dkk, 2004 : Sindroma Diare RSUD Dr. Soetomo, Surabaya : Fakultas Kedokteran Unair.

Sugiyono, 1999 : Metode Penelitian Bisnis, Bandung : CV. Alfa Beta.

Suharsimi Arikunto, 2006 : Prosedur Penelitian Suatu Pendekatan Praktik, Jakarta : Rineka Cipta.

Suharyono, 1999 : Gastroentrologi Anak Praktis, Jakarta : Balai Penerbit FKUI.

Suliha, U., dkk, 2002 : Pendidikan Kesehatan dalam Keperawatan, Jakarta : EGC.

Sunaryo, 2004 : Psikologi untuk Keperawatan, Jakarta : EGC.

Suraatmaja, S., 2005 : Gastroentrologi Anak, Jakarta : CV Sagung Seto.

Wong, D., 2008 : Buku Ajar Keperawatan Pediatrik, Jakarta : EGC. 